\title{
Pharmacokinetics and pharmacodynamics for the clinician
}

\section{Overview of terminology}

Figure 1 shows the most important factors governing the "dose-response" relationship for a drug. The relationship between dose and resulting concentration in the blood is called the drug's pharmacokinetics. A simple definition of pharmacokinetics is "What the body does to the drug." The relationship between drug concentration in the blood and the degree of drug effect is called pharmacodynamics. A simple definition of pharmacodynamics is "What the drug does to the body." Blood transports the drug into the body tissues, especially the biophase, which is the site of action. The biophase consists of the specific components of a tissue (membranes, receptors, enzymes) where the drug exerts its pharmacological effect. The actual anatomical site of a drug's biophase may be difficult to identify. The location of the biophase within tissues of the body prevents direct physical measurement of drug concentrations at these sites of action.

By measuring the drug effect and blood concentration precisely and frequently, one can characterize two components of the biophase: (1) the time for equalization of drug concentration in the biophase with that in blood, and (2) the "apparent" drug concentration in the biophase that can be predicted by the known concentration in blood. The time delay between changes in drug concentration in the blood and measured changes in drug effect determines the methematical first-order rate constant, $\mathrm{k}_{\mathrm{e} 0}$. This rate constant can be used to calculate the half-time of the equilibration between drug concentration in the blood and drug effect, $\mathrm{t}_{\mathrm{e} 0}$. The parameter becomes an important descriptor of the rate of onset of drug effect and has significant relevance in anaesthesia. The $t_{t} k_{e 0}$ concept will be discussed in greater detail in this article.

\section{Pharmacokinetic concepts}

Various decriptive terms such as volume of distribution, distribution clearance, metabolic clearance, and terminal elimination half-life characterize the pharmacokinetic profile of a drug. Although the clinician can easily increase the drug concentration in blood, only the patient's pharmacokinetic processes can decrease the drug concentration. To decrease blood levels, the physician must stop or decrease the rate of drug administration. Two main processes are then responsible for lowering

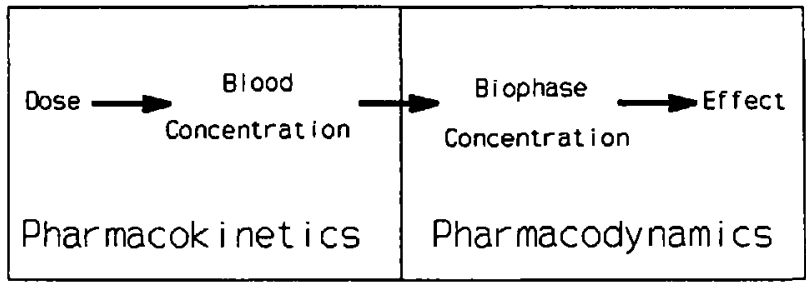

FIGURE 1 The relationship between drug dose, concentrations in the blood and biophase, and effect.

drug concentrations, distribution of drug out of the central distribution volume $\left(V_{1}\right)$ into the peripheral distribution volumes and elimination of the drug from the body. Usually distribution causes the most rapid decrease in drug concentrations.

If a drug has a high rate of metabolism (i.e., high metabolic clearance), then this process can be as important as the distribution of drug in causing the blood concentrations to decline. The relative contribution of distribution and metabolism in decreasing plasma drug concentrations changes over time following an IV bolus. Initially, distribution is more important. If the volumes of distribution are large, then distribution will be able to produce large decreases in the plasma concentration. After drug concentrations in the periphery have equilibrated with the concentrations in the plasma, metabolism becomes the predominant mechanism for reducing plasma drug concentrations.

For most drugs, the curve for plasma concentration (on a log scale) over time after a bolus injection resembles that in Figure 2. Two distinct phases in the decline of plasma concentration are apparent. The first is the distribution phase, which begins immediately after injection of the bolus. This phase is characterized by very rapid movement of the drug from the blood to the vessel-rich tissues, followed by further movement into less well-perfused tissues, such as muscle or skin. The second is the elimination phase, represented by the straight line that

From the Departments of Anesthesia and Medicine (Clinical Pharmacology), Stanford University School of Medicine, Palo Alto, CA. 


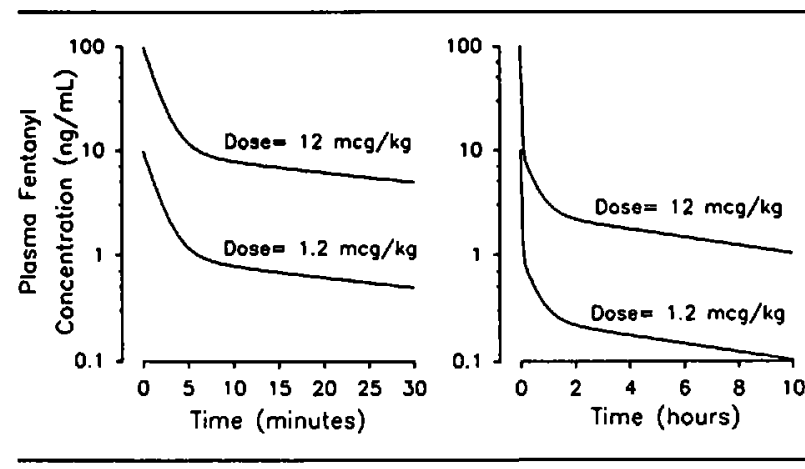

FIGURE 2 Plasma concentration vs time after rapid IV administration of a low- and high-dose bolus of fentanyl. The figure on the left expands the first $30 \mathrm{~min}$ of the figure on the right.

characterizes the terminal portion of the plasma concentration vs time plot. Elimination of drug from the body actually occurs throughout the course of plasma concentration decline.

Intravenous drugs in anaesthesia generally follow linear pharmacokinetics, i.e., the dose of drug administered does not alter the shape of the concentration vs time curve when drawn on a log scale. However, the magnitude changes relative to the amount of drug given. Figure 2 shows that the plasma concentration curve following 12 $\mu \mathrm{g} \cdot \mathrm{kg}^{-1}$ of fentanyl looks identical to the concentration curve following $1.2 \mu \mathrm{g} \cdot \mathrm{kg}^{-1}$ of fentanyl, except that the concentration values for the larger dose are an order of magnitude greater at all points shown. The decrease in the concentration of a drug in blood can be described mathematically. The slope of the terminal log-linear portion of the curve is the elimination rate constant. The half-life of elimination is the time required for the plasma concentration to decrease by $50 \%$ during the elimination phase. This half-life can be calculated as the natural log of 2 divided by the elimination rate constant (i.e., 0.693/rate constant). Rate constants for the distribution phase can also be determined. Distribution half-lives can be calculated from their rate constants, as shown for the elimination half-life.

It is possible to represent the decay of drug concentration in blood over time using mathematical (pharmacokinetic) models. Figure 3 shows a compartment model that partitions the body into three different compartments. The central compartment represents the initial mixing volume into which we inject the drug. It consists of some fraction of the plasma and the very rapidly equilibrating (vesselrich) tissues such as brain, heart, liver, and kidney. The initial distribution phase represents equilibration of the central compartment with another compartment, which probably consists of less vessel-rich tissues such as muscle and skin. A second, slower, distribution phase may represent distribution to tissues such as bone and fat.

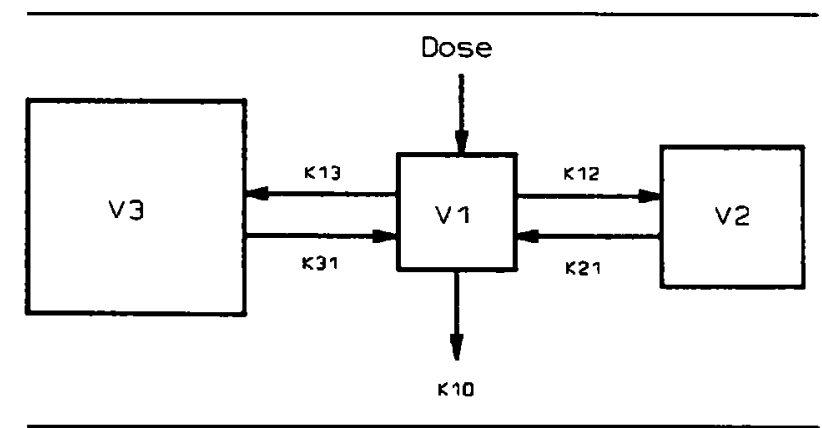

FIGURE 3 Representation of a three-compartment pharmacokinetic model. $V_{1}, V_{2}$ and $V_{3}$ represent the comparment volumes. $K 10$, $K 12, K 21, K 13$, and $K 31$ represent the transfer constants between compartments.

Care must be taken in speculating which tissues compose the various compartments of a pharmacokinetic model. The compartments are only a mathematical concept that allows us to envision a structure in the body to account for the decrease in plasma concentration of a drug. The examples mentioned are based on our understanding of drug distribution gathered by physiological models. Accurate identification of the tissues constituting the various compartments would require the gathering of actual tissue samples and measurement of drug concentrations over time, a process that is not possible in people.

If a drug appears to have only one distribution phase, its pharmacokinetic profile is described by a "two-compartment" model (the central compartment and the distribution compartment). By relating the dose of a drug to its plasma concentration, one can calculate the volume of the central compartment $\left(V_{1}\right)$ and the overall volume of distribution at steady-state $\left(\mathrm{Vd}_{\mathrm{ss}}\right)$, the latter being the algebraic sum of the volumes of the central and peripheral compartments.

The extent to which distribution decreases the plasma concentration is partly a function of the size of the volume of distribution at steady-state $\left(V_{d s}\right)$. The $V d_{s s}$ of some drugs can be very large, even exceeding the mass of the body. Because drug concentration is measured only in plasma and not in tissues, calculation of $\mathrm{Vd}_{\mathrm{ss}}$ assumes that partitioning between plasma and all tissues is at steadystate, 1.0. The value for $\mathrm{Vd}_{s s}$ can exceed total body volume if, at steady-state, drug concentrations in tissue exceed those in plasma. Although the free drug is in equilibrium throughout the body at steady-state, the total drug in some tissues is greater than in others because of binding of the drug to tissue components.

Systemic clearance is the removal of drug from the body, generally by the liver or kidney. Drug clearance is the volume of blood or plasma completely cleared of drug per unit time. Just as creatinine clearance is a measure of the efficiency of renal function, drug clearance is a 


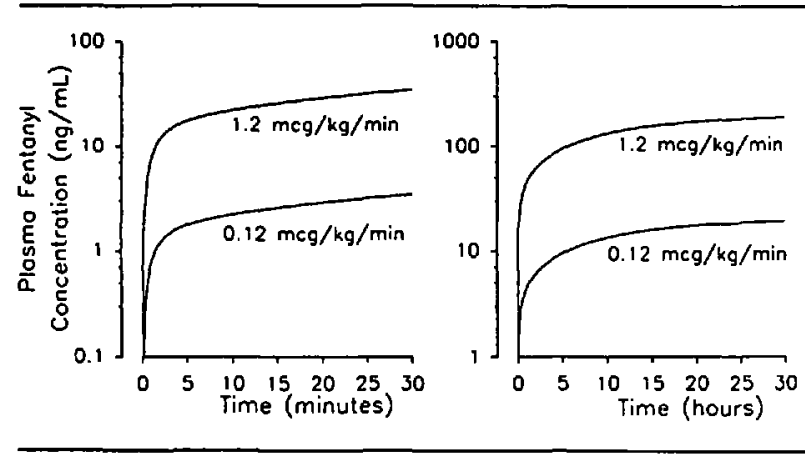

FIGURE 4 Plasma concentration vs time for a $30 \mathrm{hr}$ infusion of fentanyl given at a low and high rate.

measure of the ability of the body to eliminate a drug. Just as creatinine clearance describes a property of the kidney independent of the serum creatinine concentration, the systemic clearance of a drug is a property of the elimination organs and is independent of drug concentration.

For "one-compartment" models (that is, for drugs having an extremely short distribution phase), the elimination half-life of a drug can be calculated from its $\mathrm{Vd}$ and clearance $(\mathrm{Cl})$ :

\section{Elimination half-life $=0.693(\mathrm{Vd} / \mathrm{Cl})$}

0.693 is the natural $\log$ of 2 . Unfortunately, none of the drugs used in anaesthesia can be described by onecompartment models, and the relationship between halflives, volumes, and clearance becomes much more complex for multicompartmental models. However, this equation demonstrates that larger volumes tend to increase half-lives, whereas larger clearances tend to decrease half-lives.

Although the previous discussion of pharmacokinetic concepts pertains to rapid IV administration of a bolus, the same principles apply to continuous infusion. If the same dose of fentanyl given as rapid IV bolus administration in Figure 2 were given as a constant infusion over 10 min, because some of the drug is distributed during infusion, the peak blood concentration is lower than the peak blood concentration in Figure 2. If a drug were infused continuously for a long period of time (Figure 4), one would ultimately achieve a steady-state in which the rate of drug administration would equal the rate of drug removal from the body. Steady-state does not occur until infusion has exceeded three or four terminal elimination half-lives of the drug. Infusing the drug at a more rapid rate does not shorten the time to steady-state but only increases the ultimate blood concentration of the drug that will exist at steady-state.

When a drug is given as a bolus followed by a continuous infusion, the subsequent plasma concentra-

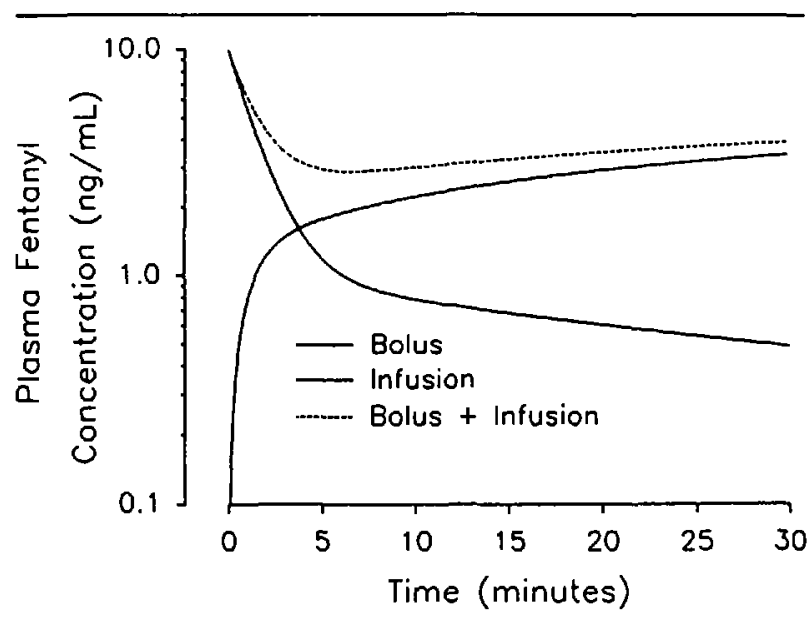

FIGURE 5 Plasma concentration vs time for the bolus dose of fentanyl given in Figure 2 and the infusion given in Figure 4.

tions can be predicted by adding the results of the two processes. Figure 5 shows the blood concentration vs time curves for the bolus of fentanyl given in Figure 2 and the continuous infusion given in Figure 4. The combined response is also displayed. This principle of additivity (or superposition) of blood concentrations occurs because of the first-order (linear) nature of drug disposition.

\section{Drug concentration in the biophase}

Earlier discussion of the biophase (site of action) defined $\mathrm{t}_{\mathrm{i}} \mathrm{k}_{\mathrm{e} 0}$ as the half-time of equilibration between drug concentration in the blood and drug effect. Following either a bolus injection or a continuous infusion, drugs with a short $t_{2} k_{-0}$ will tend to have a rapid onset of drug effect, whereas drugs with a long $t_{\frac{1}{2}} k_{\mathrm{e} 0}$ will have a delayed onset of drug effect. Equilibration is rapid for the IV anaesthetics thiopentone and propofol and the opioid alfentanil $\left(t_{1} k_{c 0} 1-2 \mathrm{~min}\right)$, intermediate for the opioids fentanyl and sufentanil and the nondepolarizing muscle relaxants $\left(\mathrm{t}_{2} \mathrm{k}_{\mathrm{eO}}>4-7 \mathrm{~min}\right)$, and slow for morphine $\left(\mathrm{t}_{9} \mathrm{k}_{\mathrm{eO}}\right.$ $>10 \mathrm{~min}$ ).

Why is the biophase important? If a constant, stable drug effect is desired, it is necessary to strive for a constant drug concentration at the site of action, the biophase. Carefully designed dosing regimens can produce a constant degree of drug effect. In contrast, frequent repeated IV bolus injections cause fluctuations in plasma and biophase concentrations and therefore drug effect. Figure 6 shows the plasma concentrations and apparent biophase concentrations after an IV bolus injection of fentanyl at three values for $\mathrm{t}_{\mathrm{a}} \mathrm{k}_{\mathrm{co}}: 1 \mathrm{~min}, 7 \mathrm{~min}$ (the actual measured value for fentanyl), and $15 \mathrm{~min}$. As $\mathrm{t}_{2} \mathrm{k}_{\mathrm{e} 0}$ increases, the time to reach the peak apparent biophase concentration also increases, but not in direct proportion to the value of $t_{i} k_{e 0}$. As the time to peak apparent 


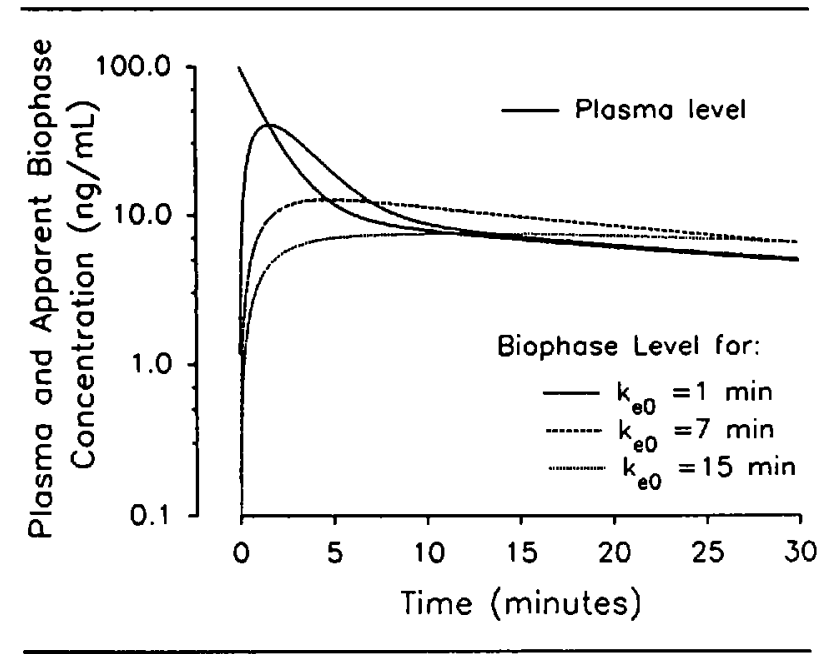

FIGURE 6 Plasma concentrations vs time following a bolus dose of fentanyl, and the apparent drug concentrations in the biophase that would occur for different values of $t_{\frac{1}{2}} k_{e 0}$.

biophase concentrations increases, the time to peak drug effect increases. If the dose and drug concentration in the blood do not change, a larger $t_{1} k_{e 0}$ would also produce lower apparent biophase concentrations and less drug effect following a bolus. Slow equilibration between drug concentrations in the blood and biophase allows more drug to be redistributed to non-biophase sites and therefore results in less drug effect.

Figure 7 shows the plasma concentrations and the apparent biophase concentrations after a low- and highdose IV bolus injection of fentanyl. The apparent concentrations were calculated using the $\mathrm{t}_{\mathrm{i}} \mathrm{k}_{\mathrm{co}}$ measured for fentanyl. A larger dose produces higher drug concentrations in the blood, which in turn creates higher apparent concentrations in the biophase. If a certain threshold of

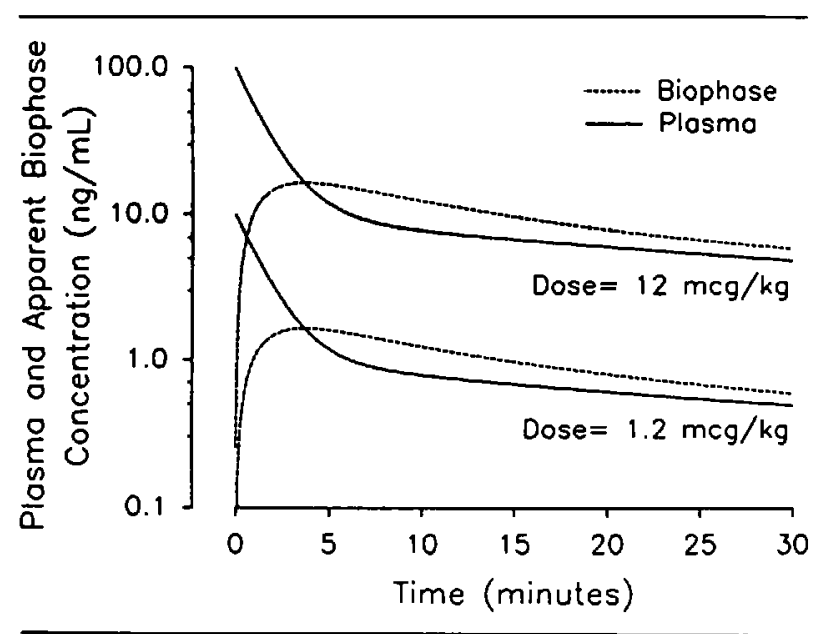

FIGURE 7 Plasma and apparent biophase concentrations vs time following a small and large fentanyl bolus.

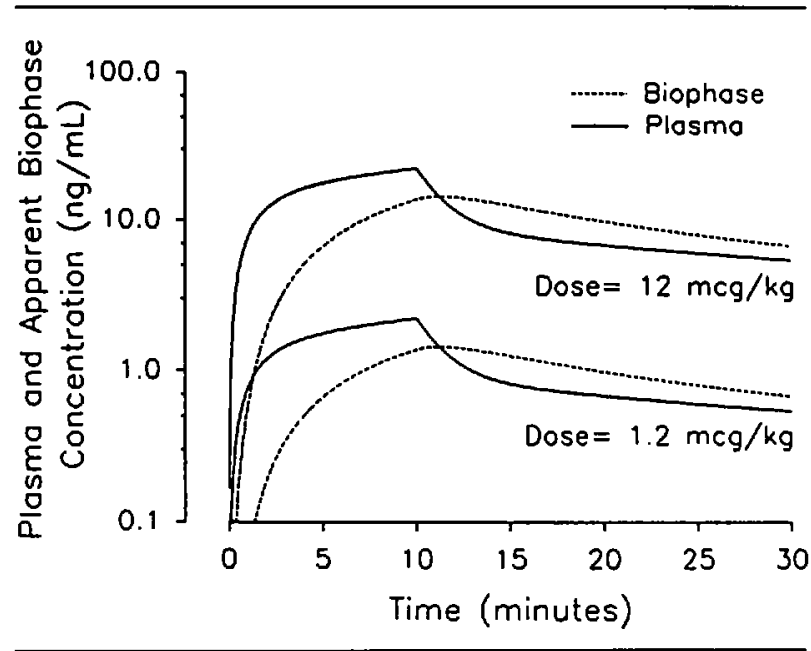

FIGURE 8 Plasma and apparent biophase concentration vs time after a 10 min infusion of a low and a high dose of fentanyl.

biophase concentrations is needed to obtain a defined drug effect, the larger dose would reach this threshold earlier. For this reason, an increase in the dose administered intravenously produces a more rapid onset of drug effect. In addition, side-effects can become more obvious and prominent with rapid administration of larger doses. However, changes in the size of the dose do not affect the actual time to peak drug concentration in the biophase.

Figure 8 shows the plasma concentrations and the apparent biophase concentrations after a $10 \mathrm{~min}$ infusion of a low- and high-dose of fentanyl. Although the apparent biophase concentrations continue to lag behind the plasma concentrations, the degree of disequilibrium is less than after IV bolus administration. This characteristic predicts that the observed drug effect parallels the drug concentration in the plasma to a greater extent during an infusion than after an IV bolus.

Why is understanding the apparent drug concentration in the biophase important when giving an infusion? The blood is not the site of drug effect. The effect of a drug is determined by its concentration in the biophase. During infusion of any anaesthetic drug, the clinician must appreciate to what degree drug concentration in the biophase lags behind that in the blood. Drug dosing must be designed to achieve the maximum concentration in the biophase when it is clinically important to have the maximum drug effect. Understanding the basic relationship between the $t_{\frac{1}{2}} k_{e 0}$ of the drug and rate of drug administration allows one to achieve optimal drug effect through manipulation of the infusion scheme.

\section{Pharmacodynamic concepts}

The clinical practice of anaesthesia would be simpler if it were easy to measure the effect of an anaesthetic drug 


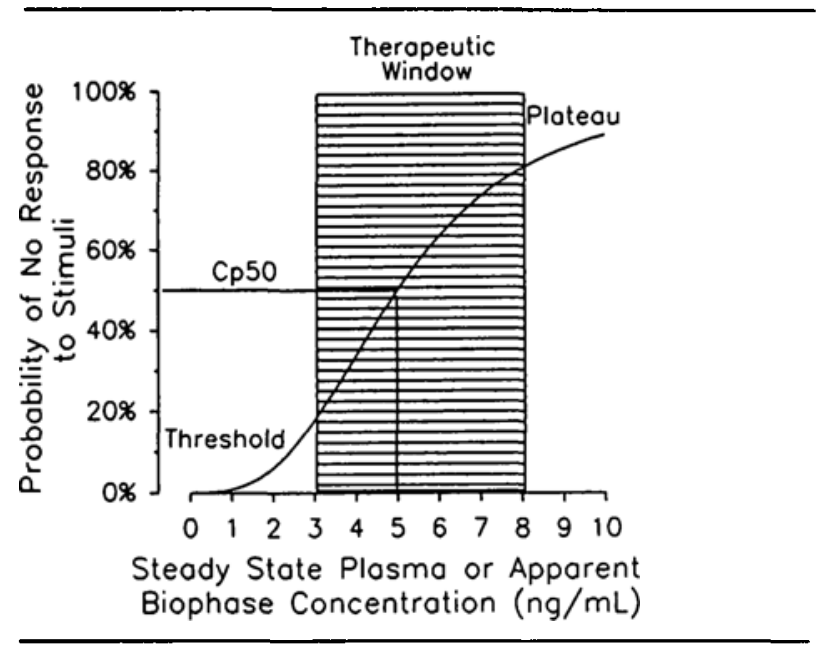

FIGURE 9 Plasma concentration of fentanyl at steady statc vs the probability of no clinical response to noxious stimuli. Also shown are the $\mathrm{C}_{\mathrm{P}_{\text {so }}}$ and the therapeutic window.

precisely. For muscle relaxants, such measurement is possible by stimulating a peripheral nerve and observing movement in the affected muscle group. For other drugs such as the IV hypnotics and opioids, the clinical effect is much harder to measure. The traditional signs of inadequate anaesthesia are movement or haemodynamic changes in response to noxious perioperative stimuli. However, it is more difficult to detect excessive anaesthesia, particularly for the opioids. Excessive central nervous system depression (drug overdose) may manifest as unacceptable haemodynamic depression or prolonged emergence from anaesthesia.

Pharmacodynamic research involves quantitating the relationship between drug concentrations and drug effect. Ideally, we would like to measure the drug concentration at the biophase, but this is not possible. Fortunately, we can characterize the transfer process between the plasma and the biophase by comparing the time course of drug effect with the time course of drug concentration in the blood. This allows calculation of the "apparent" biophase concentration over time.

The biophase concentration is only "apparent," and not "real," because it is inferred from the drug concentration in the blood. As a straightforward example, since the biophase is necessarily in stable equilibrium with the blood at steady-state (for example, following a very long infusion), we can infer that the concentration in the biophase equals the concentration in the blood. Thus, at steady-state, the "apparent" biophase concentration equals the blood concentration. When drug concentrations are not at steady-state, the apparent biophase concentration is the drug concentration in the blood that would, at steady-state, produce the same degree of drug effect. Although it may seem confusing or even contradictory,

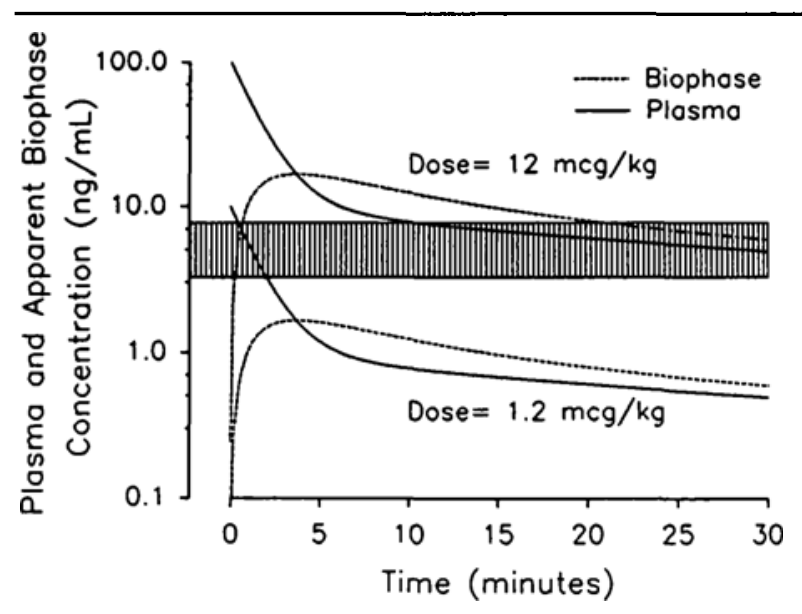

FIGURE 10 Plasma and apparent biophase concentration vs time after a low- and high-dose bolus of fentanyl, as given in Figure 2. The therapeutic window is shown on the graph.

the terms "apparent biophase concentration" and "steadystate drug concentration" are often used interchangeably when discussing concentration-effect relationships.

It is possible to define the therapeutic window as the range of drug concentrations that result in desired clinical effects. Figure 9 displays the typical shape of the relationship between the apparent biophase concentration (or steady-state blood concentration) and drug effect. The midpoint of this curve is the $\mathrm{Cp}_{50}$, the concentration of drug in the blood, at steady-state, that produces $50 \%$ of the maximal drug response. This pharmacodynamic variable is a measure of the individual subject's sensitivity to the drug.

Figure 10 shows not only the blood and biophase concentrations after two different bolus doses of fentanyl with $70 \%$ nitrous oxide but also the therapeutic window for fentanyl, the criterion being intraoperative haemodynamic control. The larger dose of fentanyl produces adequate biophase concentrations for a longer period of time and also results in a more rapid onset of detectable opioid effect. Examining only the blood concentrations would be deceptive. The high blood concentrations immediately after IV bolus injection do not immediately translate into therapeutically adequate concentrations in the biophase because of the finite time for equilibration between blood and biophase. The biophase concentration from the lower dose never enters the therapeutic window.

It is important to note that therapeutic windows of drug effect can change depending on the perioperative stimuli. The concentration of opioid at the site of drug effect must generally be higher for suppression of noxious intraoperative stimuli than for adequate postoperative ventilation. Fortunately, the level of noxious stimulation decreases towards the conclusion of surgery. As a result, the 
concentration of opioid at the site of effect necessary to achieve haemodynamic stability during wound closure, in the presence of $\mathrm{N}_{2} \mathrm{O}$ or a potent vapour, is similar to that associated with minimal respiratory depression in the absence of $\mathrm{N}_{2} \mathrm{O}$ or a potent vapour. As a result, it is usually possible to decrease the opioid infusion rate during the anaesthetic until the concentration of opioid at the site of effect is very close to, if not less than, the concentration desired at the conclusion of the anaesthetic. Intraoperative infusion of opioid must be designed for this pharmacodynamic reality.

Another important pharmacodynamic consideration is that moderate variability exists between patients. For reasons not understood, the therapeutic window of drug effect can vary $30 \%$ to $60 \%$. Therefore, the therapeutic window of drug effect represents only an average starting point for initiating therapy. The individiual patient's response to the drug and to perioperative events should guide subsequent adjustment of dosing. Titrating drug infusion to clinical end-points individualizes infusion of anaesthetics and in that way overcomes pharmacodynamic variability.

(Adapted from the manual entitled "The Scientific Basis of Infusion Techniques in Anesthesia by DR Stanski, SL Shafer and SE Kern, published by Bard MedSystems, North Reading MA.)

\section{Suggested reading}

Hug CC Jr. Pharmacokinetics of drugs administered intravenously. Anesth Analg 1978; 57: 704-23.

Scott JC, Ponganis KV, Stanski DR. EEG quantitation of narcotic effect: the comparative pharmacodynamics of fentanyl and alfentanil. Anesthesiology 1985; 62: 234-41.

Ausems ME, Hug CC Jr, Stanski DR, Burm AGL. Plasma concentrations of alfentanil required to supplement nitrous oxide anesthesia for general surgery. Anesthesiology 1986; 65: 362-73.

Ebling WF, Lee EN, Stanski DR. Understanding pharmacokinetics and pharmacodynamics through computer simulation: I. The comparative clinical profiles of fentanyl and alfentanil. Anesthesiology 1990; 72: 650-8.

Shafer SL, Varvel JR. Pharmacokinctics, pharmacodynamics and rational opioid sclection. Anesthesiology 1991 (in press). 


\section{Pharmacocinétique et pharmacodynamie pour le clinicien}

Donald R. Stanski MD

\section{Un survol de la terminologie}

La Figure 1 montre les facteurs les plus importants qui gouvernent la relation entre la dose et la réponse pour une substance. La relation entre la dose et la concentration obtenue dans le sang s'appelle la pharmacocinétique de la substance. Une definition simple de pharmacocinétique sera «ce que l'organisme fait à la substance». La relation entre la concentration dans le sang et l'effet obtenu s'appelle la pharmacodynamie. Une définition simple de pharmacodynamie sera «ce que la substance fait à l'organisme». Le sang transporte les substances dans les tissus, surtout la biophase, elle-même définie comme le site d'action. La biophase comprend les composantes spécifiques d'un tissu (membrane, recepteurs, enzymes) ou la substance exerce son effet pharmacologique. L'emplacement anatomique exact d'une biophase peut être difficile à définir. Comme cette biophase se retrouve dans les tissus de l'organisme, il devient difficile de faire des mesures directes des concentrations de substances au niveau de ces sites d'action.

En mesurant l'effet des substances et leur concentration sanguine de manière précise et fréquente, l'on peut définir deux composantes de la biophase : 1) le temps d'équilibration entre la concentration dans la biophase et celle dans le sang, et 2) la concentration «apparente » dans la biophase qui peut être prédite par les concentrations connues dans le sang. L'intervalle entre les changements de concentration dans le sang et les modifications mesurées de l'effet déterminent la constante mathématique de premier ordre $k_{e 0}$. Cette constante sera utilisée pour calculer la demi-vie de l'atteinte de l'équilibre entre la concentration de la substance dans le sang et l'effet thérapeutique, $4 \mathrm{k}_{\mathrm{e} 0}$. Ce paramètre devient un important indicateur du temps d'apparition de l'effet médicamenteux et a une pertinence certaine en anesthésie. Le concept de la tị $k_{\mathrm{e} 0}$ sera élaboré plus en détail dans cet article.

\section{Concepts applicables à la pharmacocinétique}

Plusieurs termes descriptifs tels que volume de distribution, clearance de distribution, clearance métabolique, et demi-vie d'élimination terminale, vont caractériser le profil pharmacocinétique d'une substance. Même si le clinicien peut facilement augmenter la concentration d'une substance dans le sang, seuls les processus pharma-

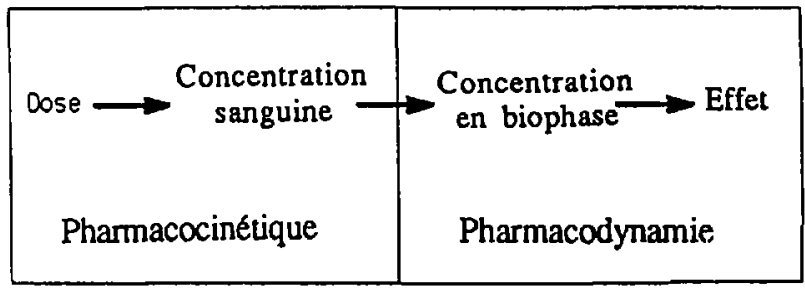

FIGURE 1 Relation entre dose/concentration dans le sang dans la biophase et effets.

cocinétiques du patient pourront diminuer cette concentration. Pour diminuer les niveaux sanguins, le médecin doit cesser ou diminuer le taux d'administration des substances. Deux phénomènes principaux sont dès lors responsables de la diminution de la concentration des substances, $1^{\circ}$ la distribution hors du volume de distribution central $\left(V_{1}\right)$ dans les volumes de distribution périphériques, et $2^{\circ}$ l'élimination de la substance de l'organisme. Habituellement, la distribution amène les diminutions les plus rapides de concentration.

Si une substance a un taux élevé de métabolisme (i.e., une clearance métabolique élevée), dès lors cette caractéristique peut être aussi importante que la distribution pour amener une diminution des concentrations sanguines. La contribution relative de la distribution et du métabolisme dans la diminution des concentrations plasmatiques va varier dans le temps, à la suite d'un bolus intra-veineux. Au début, la distribution est plus importante. Si les volumes de distribution sont importants, dès lors la distribution pourra amener des diminutions importantes de concentration plasmatique. Après que les concentrations en périphérie sont devenues en équilibre avec les concentrations plasmatiques, le métabolisme devient alors le mécanisme dominant de la réduction des concentrations plasmatiques.

Pour la plupart des substances, la courbe des concentrations plasmatiques (sur une échelle logarithmique) par rapport au temps, après un bolus, ressemble à celle que l'on retrouve dans la Figure 2. Deux phases distinctes deviennent apparentes dans la diminution de la concentration plasmatique. La première est la phase de distribution, qui commence immédiatement après l'injection du bolus. Cette phase est caractérisée par un mouvement très rapide 


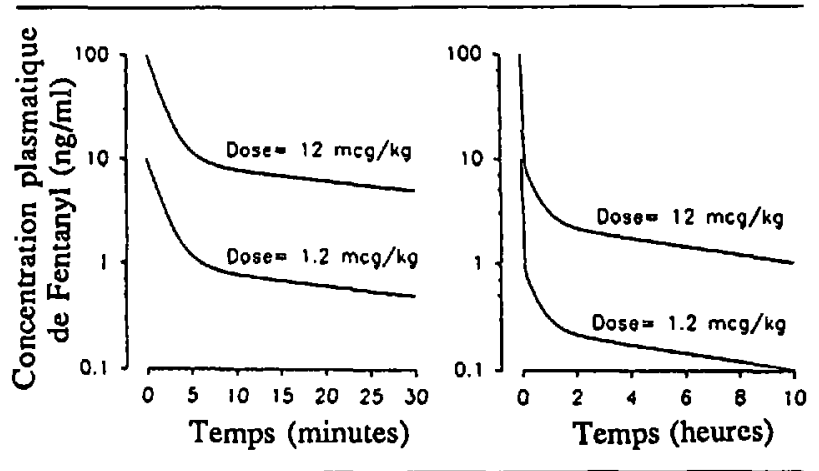

FIGURE 2 Courbe de la concentration plasmatique dans le temps après administration après intra-veineuse rapide d'un bolus faible et important de fentanyl. La Figure de gauche développe les premières 30 minutes de la Figure de droite.

de la substance à partir du sang vers les tissus richement vascularisés, suivie par la suite d'un déplacement vers les tissus moins bien perfusés, tels les muscles ou la peau. La deuxième phase en est une d'élimination, représentée par la ligne droite qui caractérise la portion terminale de la courbe concentration/temps. L'élimination d'une substance de l'organisme se produit en fait pendant toute la période où il y a diminution de concentration plasmatique.

Les substances anesthésiques intra-veineuses vont pour la plupart suivre un processus pharmacocinétique linéaire, c'est-à-dire que la dose de substance administrée ne modifiera pas la courbe concentration/temps lorsque tracée sur une échelle logarithmique. Cependant, l'ordre de grandeur va être modifié selon la quantité de substance donnée. La Figure 2 montre que la courbe de concentration plasmatique consécutive à une injection de $12 \mathrm{mg} \cdot \mathrm{kg}^{-1}$ de fentanyl semble identique à la courbe qui suit une injection de $1,2 \mathrm{mg} \cdot \mathrm{kg}^{-1}$ de fentanyl, sauf que les valeurs de concentrations de la dose plus élevée sont d'un tout autre ordre de grandeur sur tous les points de la courbe. La diminution de concentration d'une substance dans le sang peut être décrite sur une base mathématique. La pente de la portion terminale log-linéaire de la courbe est sa constante d'élimination. La demi-vie d'élimination est le temps requis pour que la concentration plasmatique diminue de $50 \%$ pendant la phase d'élimination. Cette demi-vie peut être calculée en divisant le logarithme naturel de 2 par la constante d'élimination (i.e., 0,693/ constante d'élimination). Les constantes pour les phases de distribution peuvent être aussi calculées. Les demi-vies de distribution peuvent être calculées à partir de leur constante, de la même manière qu'on a pu le démontrer pour la demi-vie d'élimination.

On peut représenter aussi la décroissance de la concentration sanguine d'une substance dans le temps en utilisant des modèles mathématiques (pharmacocinétique). La Figure 3 montre un modèle de compartiment qui divise le

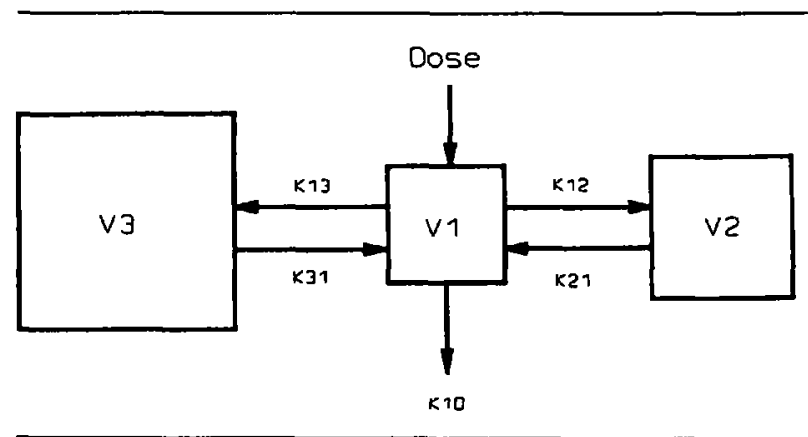

FIGURE 3 Représentation d'un modèle pharmacocinétique à trois compartiments. $V_{1}, V_{2}$ et $V_{3}$ représentent les volumes des compartiments. K10, KII, K21, K13 et K31 représentent les constantes de transfert entre les compartiments.

corps en trois compartiments différents. Le compartiment central représente le volume initial dans lequel nous injectons la substance. Ce volume est composé d'une partie du plasma et des tissus richement vascularisés tels que le cerveau, le cœur, le foie et le rein. La phase de distribution initiale représente une équilibration du compartiment central avec un autre compartiment, qui comprend probablement les tissus moins riches en vaisseaux tels que les muscles et la peau. Une deuxième phase de distribution, plus lente, représentera probablement une distribution vers les os et les graisses.

Il faut être prudent lorsque l'on veut attribuer une composition tissulaire spécifique aux différents compartiments des modèles pharmacocinétiques. Les compartiments sont seulement des concepts mathématiques qui nous permettent de visualiser un modèle du corps qui tienne compte de la diminution plasmatique d'une substance. Les exemples mentionnés sont fondés sur notre compréhension de la distribution des substances telles que recueillie à partir de modèles physiologiques. L'identification précise des tissus qui pourraient constituer les différents compartiments demanderait le prélèvement d'échantillons tissulaires et la mesure des concentrations de substances dans le temps, un processus qu'il n'est pas possible de faire chez l'homme.

Si une substance semble avoir une seule phase de distribution, son profil pharmacocinétique est décrit par un modèle à deux compartiments (le compartiment central et le compartiment de redistribution). En établissant une relation entre la dose de substance et sa concentration plasmatique, on peut dès lors calculer le volume du compartiment $\left(V_{1}\right)$ et le volume total de distribution en phase d'équilibre $\left(\mathrm{Vd}_{\mathrm{ss}}\right)$, et ce dernier est composé de la somme algébrique des volumes des compartiments central et périphérique.

La dimension de la participation de la distribution dans la diminution de la concentration plasmatique est en partie fonction du volume de distribution en phase d'équilibre 
$\left(V d_{s s}\right)$. Le $V d_{s s}$ de certaines substances peut être très important, et même dépasser la masse corporelle. Puisque la concentration des substances est mesurée seulement dans le plasma et non pas dans les tissus, le calcul du $\mathrm{Vd}_{\mathrm{ss}}$ assume que le partage à l'équilibre entre le plasma et les tissus est unitaire. La valeur $\mathrm{du} \mathrm{Vd}_{\mathrm{ss}}$ peut dépasser le volume corporel total si, à l'équilibre, les concentrations tissulaires dépassent les concentrations plasmatiques. Même si la portion libre d'une substance est également distribuée à travers tout l'organisme dans la phase d'équilibre, la quantité totale de la substance dans certains tissus est plus importante que dans d'autres à cause de liaison de la substance aux composantes tissulaires.

La clearance systémique est le phénomène d'extraction de la substance de l'organisme, généralement par le foie ou le rein. La clearance d'une substance est le volume de sang ou de plasma complètement libéré de cette substance par unité de temps. De la même manière que la clearance de la créatinine est une mesure de l'efficacité de la fonction rénale, la clearance de la substance est la mesure de la capacité de l'organisme à l'éliminer. Et tout comme la clearance de la créatinine décrit une propriété du rein qui va être indépendante de la concentration sérique de créatinine, la clearance systémique d'une substance est une propriêté des organes d'élimination et sera indépendante de la concentration des substances.

Pour les modèles à un seul compartiment (c'est-à-dire pour les substances qui ont une phase de distribution extrèmement courte), la demi-vie d'élimination d'une substance pourra être calculée à partir de son volume de distribution et sa clearance $(\mathrm{Cl})$ :

demi-vie d'élimination $=0,693(\mathrm{Vd} / \mathrm{cl})$

où 0,693 est le logarithme naturel de 2 . Malheureusement, aucune des substances utilisées en anesthésie ne peut être décrite par un modèle à un seul compartiment, et les relations entre demi-vie, volume et clearance deviennent beaucoup plus complexes pour les modèles à compartiments multiples. Cependant cette équation montre que des volumes importants de distribution ont tendance à augmenter les demi-vies, alors que les clearances importantes vont les diminuer.

La discussion précédente s'appliquait à l'administration intra-veineuse rapide d'un bolus ; les mêmes principes s'appliquent aux infusions continues. La Figure 4 nous montre les courbes obtenues lorsque la dose de fentanyl donnée en bolus rapide dans la Figure 2 est administrée en infusion constante sur une période de dix minutes. Puisqu'une partie de la substance sera distribuée pendant l'infusion, le pic de concentration plasmatique dans la Figure 4 est inférieur à celui observé dans la Figure 2. Si une substance était infusée continuellement sur une longue période de temps, l'on obtiendrait finalement une

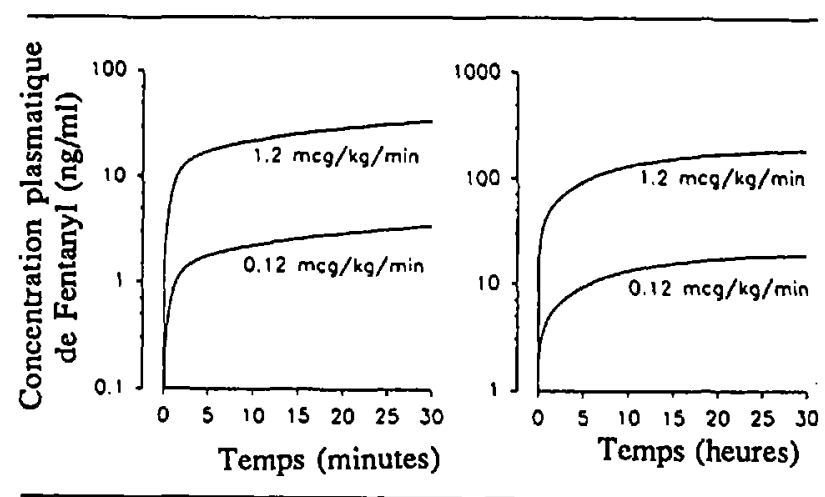

FIGURE 4 Concentration plasmatique versus temps pour les doscs de fentanyl mentionnées dans la Figure 2, sauf que la dose est maintenant donnée en infusion pendant dix minutes.

phase d'équilibre où la vitesse d'administration serait égale à la vitesse d'extraction de la substance de l'organisme. La phase d'équilibre apparaîtra seulement lorsque l'infusion se sera prolongée le temps de trois ou quatre demi-vies d'élimination terminale de la substance. L'accelération de la vitesse d'infusion ne raccourcit pas le temps d'obtention du plateau d'équilibre mais augmentera seulement la concentration finale de la substance en phase d'équilibre (steady-state). Lorsqu'un bolus est suivi d'une infusion continue, les concentrations plasmatiques pourront être prédites en combinant le résultat des deux processus. La Figure 5 montre les courbes de concentration pour le bolus de fentanyl de la Figure 2 et de l'infusion continue de la Figure 4. La réponse combinée est aussi illustrée. Ce principe d'additivité (ou de superposition) des concentrations sanguines se produit à cause de la nature linéaire de l'élimination des substances.

\section{Concentration des substances pharmacologiques dans la biophase}

Notre discussion préalable de la biophase (site d'action) a défini la formule $t_{2} k_{e 0}$ comme la demi-vie d'équilibration entre la concentration de la substance dans le sang et l'effet obtenu. A la suite d'un bolus ou d'une infusion continue, les substances avec un $t_{2} k_{e 0}$ de courte durée auront un effet rapide, alors que celles qui possèdent un long $t_{2} k_{\mathrm{e} 0}$ verront le début d'action retardé. L'équilibration est rapide pour les anesthésiques intra-veineux comme le thiopental, le propofol et l'alfentanil $\left(t_{8} k_{c 0}=\right.$ 1-2 minutes), elle sera intermédiaire pour les opiacés de type fentanyl et sufentanil ainsi que pour les musculorelaxants non-dépolarisants ( $\mathrm{t}_{2} \mathrm{k}_{\mathrm{co}}>4$ à 7 minutes), et lente pour la morphine ( $t_{2} k_{\mathrm{e} 0}>10$ minutes).

Pourquoi la biophase est-elle importante? Si l'on recherche un effet médicamenteux stable et constant, il devient nécessaire de rechercher à obtenir une concentration constante au site d'action, la biophase. Des cédules d'administration soigneusement planifiées pourront pro- 


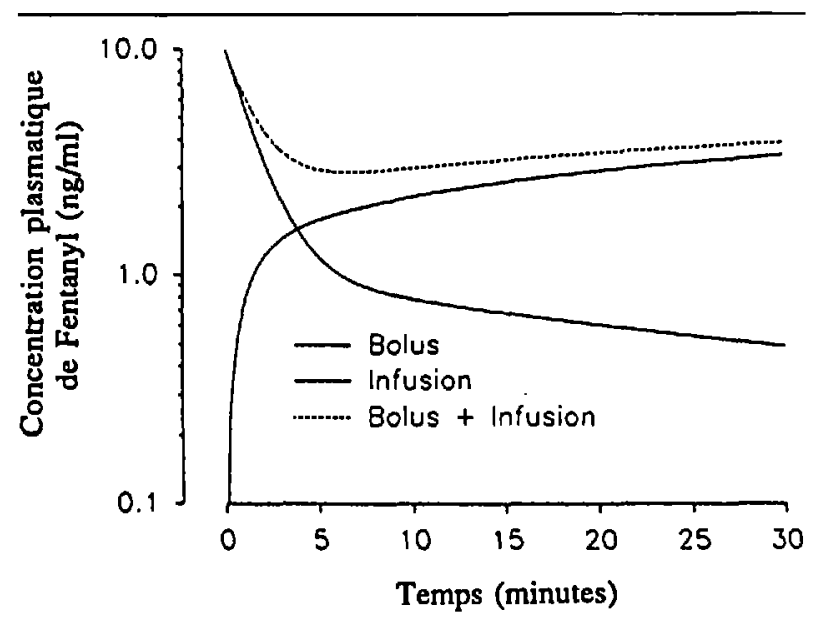

FIGURE 5 Concentration plasmatique versus temps pour le bolus de fentanyl donnce dans la Figure 2 et l'infusion mentionnece dans la Figure 4.

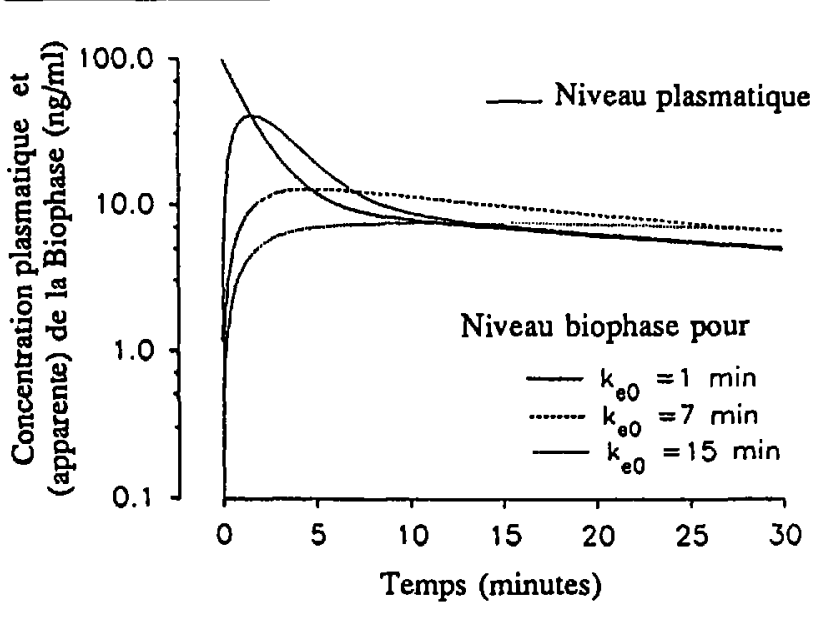

FIGURE 6 Concentration plasmatique versus temps à la suite d'un bolus de fentanyl et concentration apparente de substance dans la biophase qui devrait survenir pour différentes valcurs de $t_{\imath} k_{e 0}$.

duire un degré constant d'effets médicamenteux. Par contre, des injections répétées vont amener des fluctuations autant dans les concentiations plasmatiques que dans la biophase et donc des fluctuations dans l'effet thérapeutique. La Figure 6 montre les concentrations plasmatiques et les concentrations apparentes dans la biophase après un bolus intra-veineux de fentanyl pour trois valeurs de $t_{2} k_{e 0}$ : une minute, sept minutes (la valeur mesurée en fait pour le fentanyl), et 15 minutes. $\grave{A}$ mesure que la $t_{1} k_{\mathfrak{c} 0}$ augmente, le délai d'atteinte du pic de concentration apparente de la biophase augmente lui aussi, mais pas nécessairement en proportion directe avec la valeur de la ti $k_{e 0}$. À mesure que le temps augmente, la période nécessaire pour obtenir l'effet maximal de la

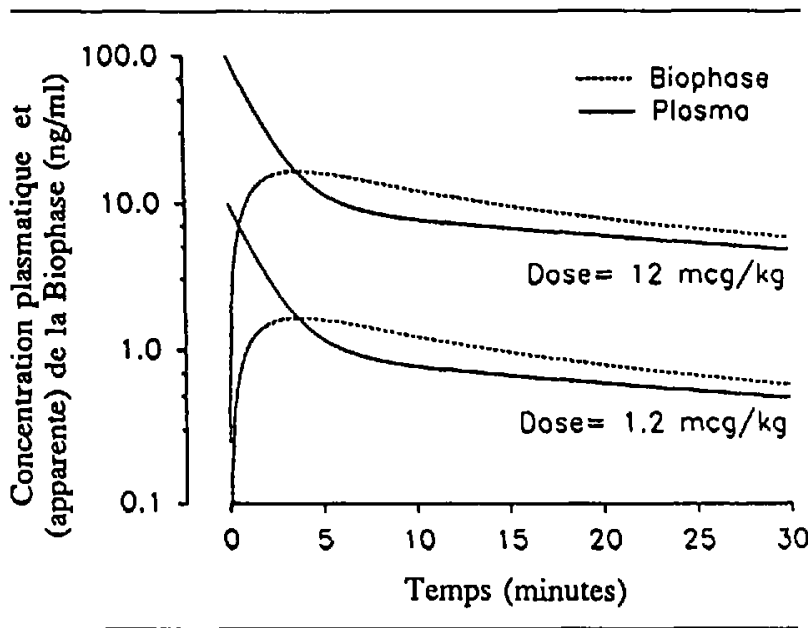

FIGURE 7 Concentration plasmatique et apparente dans la biophase versus temps à la suite d'un bolus faible et important de fentanyl.

substance augmente. Si la dose et la concentration de la substance dans le sang ne changent pas, une valeur de $4 \mathrm{k}_{\mathrm{eo}}$ plus grande va aussi amener des concentrations apparentes plus faible dans la biophase et un effet moins important à la suite d'un bolus. L'équilibration lente des concentrations de subtances entre le sang et la biophase va permettre plus de redistribution de la substance dans les sites hors de la biophase et dès lors produira un effet médicamenteux moindre.

La Figure 7 montre les concentrations plasmatiques et les concentrations apparentes dans la biophase après un bolus à faible dose et un bolus à dose élevée de fentanyl. Des concentrations apparentes ont été calculées en utilisant la $t_{1} k_{e 0}$ connue pour le fentanyl. Une dose importante produit une concentration plus élevée de fentanyl dans le sang ce qui en retour amène des concentrations apparentes plus élevées dans la biophase. S'il y a un seuil de concentration nécessaire pour obtenir un effet défini, la dose plus importante devrait atteindre ce seuil plus rapidement. Pour cette raison une augmentation de la dose administrée par voie intra-veineuse produira un début d'action plus rapide de la substance. De plus, les effets secondaires deviendront plus apparents et importants lorsqu'on administre des doses plus grandes. Cependant, les changements dans la masse de substance n'affecteront pas le temps réel d'atteinte du pic de concentration dans la biophase.

La Figure 8 montre les concentrations plasmatiques et les concentrations apparentes dans la biophase après une infusion de dix minutes d'une faible, et d'une haute dose de fentanyl. Même si les concentrations apparentes dans la biophase continuent à être décalées par rapport aux concentrations plasmatiques, le degré de déséquilibre est moins important qu'après une administration en bolus intra-veineux. Cette caractéristique permet de prédire que 


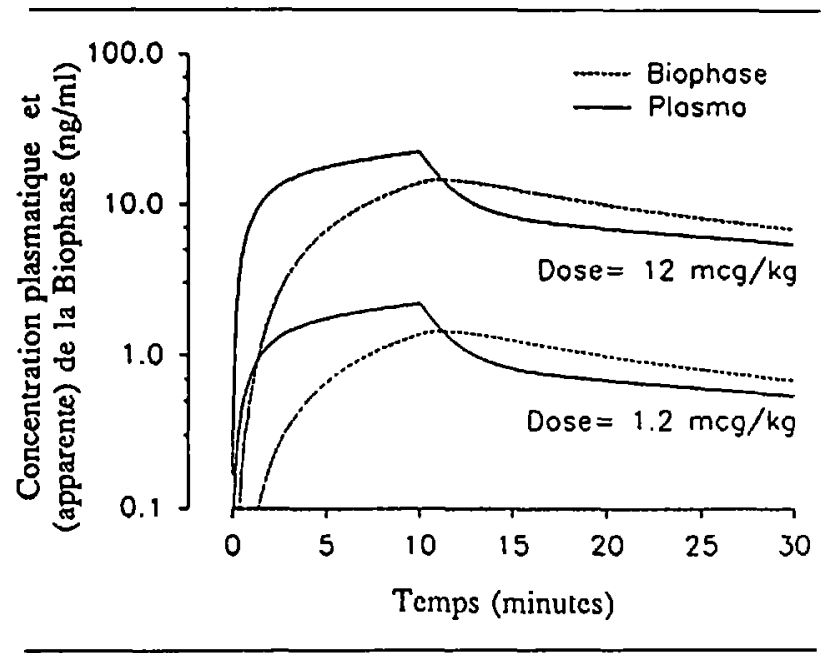

FIGURE 8 Concentration plasmatique et apparente dans la biophase versus temps après une infusion de dix minutes d'une faible et d'une haute dose de fentanyl.

les effets observés vont être en parallèle avec la concentration de la substance dans le plasma, de façon beaucoup plus prévisible après une infusion qu'après un bolus intra-veineux.

La raison pour laquelle il est important de comprendre l'importance de la concentration apparente dans la biophase lorsqu'on donne une infusion est que le sang n'est pas le site d'action de la substance. L'effet d'une substance est déterminé par sa concentration dans la biophase. Pendant l'infusion de n'importe quelle substance anesthésique, le clinicien doit être capable d'évaluer jusqu'à quel degré la concentration dans la biophase décale par rapport à celle qui se retrouve dans le sang. La posologie doit être ajustée pour obtenir une concentration maximale dans la biophase, lorsqu'il est important d'avoir l'effet maximal des substances administrées. Si l'on comprend la relation fondamentale entre le $t_{2} k_{e 0}$ d'une substance et la vitesse d'administration, on peut dès lors obtenir un effet optimal de la substance en ajustant en conséquence l'infusion.

\section{Concepts de pharmacodynamie}

La pratique clinique de l'anesthésie serait plus simple si l'on pouvait mesurer facilement l'effet d'un agent anesthésique de façon précise. On peut mesurer l'effet des musculo-relaxants en stimulant un nerf périphérique et en observant les mouvements du groupe musculaire touché. Pour d'autres substances tels que les hypnotiques intraveineux et les opiacés, l'effet clinique est plus difficile à mesurer. Les signes traditionnels d'une anesthésie inadéquate sont le mouvement ou des changements hémodynamiques en réponse à des stimulis périopératoires douloureux. Cependant, il est plus difficile de mettre en evidence un surcroit d'anesthésie, particulièrement lorsqu'il s'agit des opiacés. La dépression excessive du système nerveux central (surdose) pourra se manifester comme une dépression inacceptable sur le plan hémodynamique ou une émergence prolongée après l'anesthésie.

La recherche en pharmacodynamie veut mesurer de façon quantitative la relation entre les concentrations plasmatiques et l'effet des substances. Idéalement, nous aimerions mesurer les concentrations dans la biophase mais ceci n'est pas possible. Heureusement, on peut caractériser le processus de transfert entre le plasma et la biophase en comparant la cinétique de l'effet obtenu avec celle de la concentration dans le sang. Ceci nous permet de calculer dans le temps la concentration apparente dans la biophase.

La concentration dans la biophase est seulement apparente et non pas réelle parce qu'elle est déduite à partir des concentrations sanguines. À titre d'exemple plus simple, puisque la biophase est nécessairement en équilibre stable avec le sang pendant un plateau (par exemple à la suite d'une très longue infusion), on peut conclure alors que la concentration dans la biophase est égale à celle de la concentration sanguine. Dès lors à l'équilibre, la concentration apparente dans la biophase est équivalente à celle de la concentration sanguine. Quand les concentrations ne sont pas en plateau, la concentration apparente de la biophase sera la concentration sanguine qui produirait, pendant un plateau, le même degré d'effet médicamenteux. Même si ceci peut sembler contradictoire ou même amener de la confusion, puisque les termes " concentration apparente dans la biophase » et aussi «concentration de substance en phase de plateau » sont souvent utilisés de façon inter-changeable lorsque l'on discute des relations effet-concentration.

On peut définir la fenêtre thérapeutique comme étant le champ de concentration d'une substance où se produiront les effets cliniques désirés. La Figure 9 montre la courbe typique de la relation entre la concentration apparente dans la biophase et l'effet de la substance. Le point central de cette courbe est le $\mathrm{CP}_{50}$, la concentration de substance, dans le sang, sous condition stable, qui va amener $50 \%$ de la réponse maximale de la substance. Cette variable pharmacodynamique est une mesure de la sensibilité individuelle des sujets aux substances.

La Figure 10 montre non seulement les concentrations sanguine et en biophase après deux bolus différents de fentanyl additionné de $70 \%$ de protoxyde d'azote, mais aussi la fenêtre thérapeutique pour le fentanyl, en utilisant comme critère le contrôle hémodynamique. La dose la plus importante de fentanyl produit des concentrations adéquates dans la biophase pour une plus longue période de temps et aussi amène un début d'action plus rapide de l'effet narcotique. L'examen des seules concentrations sanguines serait trompeur. La concentration sanguine 


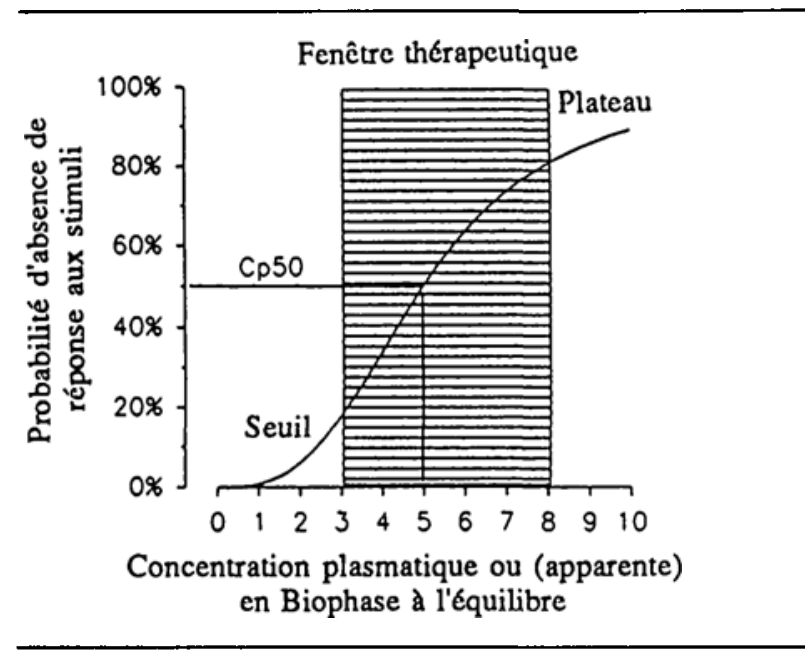

FIGURE 9 Concentration plasmatique de fentanyl à niveau continu versus la probabilité de l'absence de réponse à un stimulus douloureux. Sont montrés aussi le $\mathrm{Cp}_{50}$ et la fenêtre thérapeutique.

élevée obtenue immédiatement après un bolus intraveineux ne se traduit pas immédiatement en concentration thérapeutique adéquate dans la biophase, à cause du temps défini d'équilibration entre le sang et la biophase. La concentration en biophase obtenue à partir de la dose plus faible ne passe jamais dans la fenêtre thérapeutique.

Il est important de se rappeler que la fenêtre thérapeutique des substances peut changer selon le stimulus périopératoire. La concentration d'opiacés aux sites effecteurs doit généralement être plus élevée pour supprimer l'effet des stimuli intra-opératoires que celle nécessaire pour contrôler la ventilation post-opératoire. Heureusement, le niveau de stimulation diminue à mesure que la chirurgie s'achève. Il en résulte que la concentration d'opiacés aux sites effecteurs nécessaire pour obtenir la stabilité hymodynamique pendant la fermeture, en présence de protoxyde ou d'une vapeur puissante, est semblable à celle qui sera associée à une dépression respiratoire minimale en l'absence de protoxyde ou de vapeur anesthésique. Ceci permet habituellement de diminuer la vitesse d'infusion des opiacés pendant l'anesthésie jusqu'à ce que la concentration d'opiacés aux sites effecteurs soit très près de ou sinon moindre que la concentration désirée à la fin de l'anesthesie. Les infusions intra-opératoires d'opiacés doivent être ajustées pour tenir compte de cette réalité pharmaco-dynamique.

Il faut tenir compte aussi parmi les considérations pharmacodynamiques de l'existence d'une variabilité modérée entre les patients. Pour des raisons mal comprises, la fenêtre thérapeutique d'une substance peut varier de 30 à $60 \%$. Dès lors, la fenêtre thérapeutique d'une substance donnée représente seulement un point de départ approximatif pour débuter une thérapie. La réponse individuelle aux substances et aux événements péri-

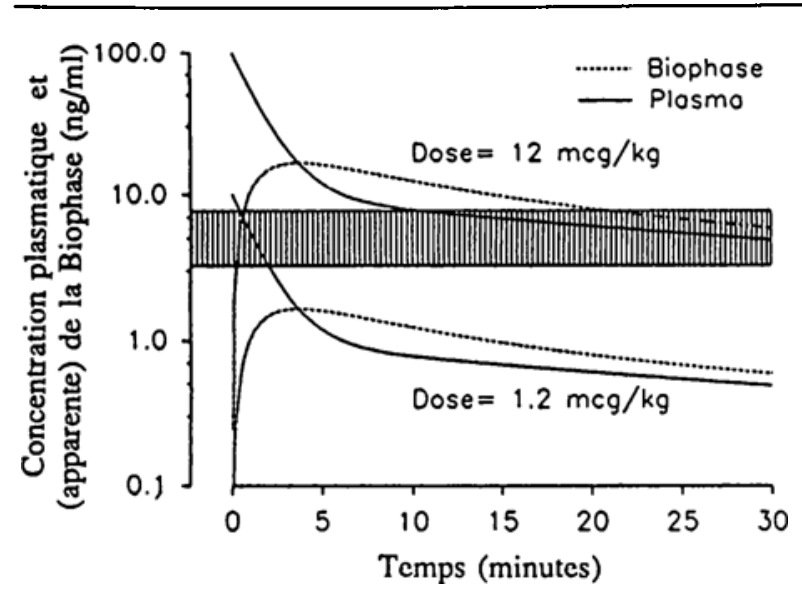

FIGURE 10 Concentration plasmatique ct apprente dans la biophase versus temps à la suite d'une bolus faible ct important de fentanyl mentionnée dans la figure 2. La fenêtre therapcutique, est démontré su la graphique.

opératoires devrait par la suite diriger l'ajustement de la posologie. L'ajustement de l'infusion en fonction d'objectifs cliniques définis permet d'individualiser l'infusion des anesthésiques et de cette façon permet de contoumer la variabilité pharmacodynamique.

(Adapté du manuel intitule «The Scientific Basis of Infusion Techniques in Anesthesia ". Par : D.R. Stanski, S.L. Shafer et S.E. Kern, publié par BArd MedSystems, North Reading MA.)

\section{Bibliographie \\ (Voir page R53)}

